\title{
ASIAB Clothing Media for Early Childhood Disaster Preparedness
}

\author{
Putri Diana Sofiya Hidayah ${ }^{1 *}$, Kartika Rinakit Adhe $^{2}$ \\ ${ }^{1}$ Department of Early Childhood Education, Universitas Negeri Surabaya, Surabaya, Indonesia \\ *Email : putrihidayah16010684049@mhs.unesa.ac.id ${ }^{1}$
}

DOI : $\underline{10.33086 / \text { cej.v3i1.1732 }}$

Submission: August 23, 2020

Revised: May 15, 2021

Accepted: May 15, 2021

\begin{tabular}{l}
\hline Keywords: \\
\hline $\begin{array}{l}\text { ASIAB clothing media, } \\
\text { disaster preparedness, } \\
\text { early childhood }\end{array}$
\end{tabular}

early childhood

\begin{abstract}
Indonesia is a country that has a high risk of natural disasters. Lack of natural ability to save themselves results in an enormous potential for children to suffer the most when a disaster occurs. Natural disaster preparedness needs to be introduced to children from an early age. Children are no longer a concern as victims who suffer the most but need to save themselves when in danger. The purpose of developing ASIAB clothing media is to determine the development, effectiveness, and feasibility of ASIAB clothing media for early childhood disaster preparedness. This type of research uses Research and Development (R\&D) with the ADDIE development model. The research subjects were media experts, material experts, and 30 teachers in TK Surabaya and Sidoarjo, East Java, Indonesia. Data collection was carried out using structured interview techniques and online questionnaires via google form accompanied by video supporting procedures for using ASIAB clothing media. Analyzing the feasibility and effectiveness of the ASIAB clothing media used qualitative and quantitative descriptive analysis with a predetermined percentage of the assessment. The results obtained show that the ASIAB clothing media is feasible in learning early childhood disaster preparedness. The feasibility of testing by media experts obtained results with the criteria "good" information "feasible" (73.33\%), testing by material experts obtained results with the criteria "very good" information "feasible" $(90.67 \%)$, testing by the teacher the results obtained with the criteria "very good" information "feasible and effective" (84.33\%). This research provides innovations in education, namely learning media for early childhood, that can assist teachers in achieving practical disaster preparedness learning objectives. Children can get hands-on experience in earthquake disaster preparedness practice using ASIAB clothing. Disaster stages such as predisaster, during the disaster, and post-disaster can also be introduced to children in a series of simulation activities. Based on the results of this assessment, the ASIAB clothing media is appropriate and effective for use in early childhood disaster preparedness learning.
\end{abstract}




\section{Kata Kunci:}

Media baju ASIAB, kesiapsiagaan bencana, anak usia dini

\begin{abstract}
Abstrak
Indonesia termasuk negara yang mempunyai resiko bencana alam tinggi. Kurangnya kemampuan alamiah menyelamatkan diri mengakibatkan besarnya potensi anak-anak menjadi korban paling menderita saat bencana terjadi. Kesiapsiagaan bencana alam perlu dikenalkan pada anak sejak dini. Anak bukan lagi menjadi perhatian sebagai korban yang paling menderita, tetapi perlu mampu menyelamatkan diri sendiri saat dalam bahaya. Tujuan pengembangan media baju ASIAB yaitu untuk mengetahui pengembangan, efektifitas dan kelayakan media baju ASIAB terhadap kesiapsiagaan bencana anak usia dini. Jenis penelitian ini menggunakan Research and Development (R\&D) dengan model pengembangan ADDIE. Subjek penelitian pengembangan yaitu ahli media, ahli materi, dan 30 guru di TK Surabaya dan Sidoarjo, Jawa Timur, Indonesia. Pengumpulan data dilakukan menggunakan teknik wawancara terstruktur dan kuesioner secara online melalui google form disertai video pendukung prosedur penggunaan media baju ASIAB. Teknik analisis kelayakan dan keefektifan media baju ASIAB menggunakan analisis deskriptif kualitatif dan kuantitatif dengan persentase penilaian yang sudah ditentukan. Diperoleh hasil bahwa media baju ASIAB dikatakan layak dalam pembelajaran kesiapsiagaan bencana anak usia dini. Kelayakan uji coba oleh ahli media diperoleh hasil dengan kriteria "baik" keterangan "layak" (73,33\%), uji coba oleh ahli materi diperoleh hasil dengan kriteria "sangat baik" keterangan "layak" $(90,67 \%)$, uji coba oleh guru diperoleh hasil dengan kriteria "sangat baik" keterangan "layak dan efektif" $(84,33 \%)$. Penelitian ini memberi inovasi baru di bidang pendidikan yaitu media pembelajaran untuk anak usia dini yang dapat membantu guru dalam mencapai tujuan pembelajaran kesiapsiagaan bencana secara praktis. Anak dapat memperoleh pengalaman langsung praktek siaga bencana gempa bumi dengan menggunakan media baju ASIAB. Tahapan bencana seperti prabencana, saat bencana dan pasca bencana juga dapat dikenalkan pada anak dalam serangkaian kegiatan simulasi. Berdasarkan hasil penilaian tersebut, maka media baju ASIAB layak dan efektif digunakan pada pembelajaran kesiapsiagaan bencana anak usia dini.
\end{abstract}

\section{A. Introduction}

Disasters can cause a lot of harm to humans and the environment. Children as victims of disasters are an essential problem, reaching tens of thousands of people. Data on victims of geological and hydrometeorological disasters according to BNPB (2018), states that there were 5,077 babies, 13,167 toddlers, and approximately 156 groups with special needs in the last four years from January 2015 to June 2018 in disaster refugee camps. Lack of natural ability to save themselves results in the enormous potential for children to suffer the most when a disaster occurs. According to Marroli (2017), who wrote about the increased preparedness carried out by the Japanese state to raise awareness of disaster preparedness from an early age, including all age levels, to reduce disaster risk.

Preparedness is a planned action to anticipate disasters (Law of the Republic of Indonesia Number 24 of 2007 concerning Disaster Management, 2007). Disaster preparedness is in the form of actual experiences. It is important to grow from an early age to save children from supporting children's growth and development through education, learning according to age stages, and children's needs and interests (Wiyani, 2016). Efforts to provide various diverse experiences also 
need to pay attention to the level of achievement of aspects of child development according to age stages. Early childhood can understand various hazard alarms such as fires, floods and earthquakes as well as knowing situations that pose a threat to themselves, especially in the context of disaster preparedness (Regulation of the Minister of Education and Culture of the Republic of Indonesia Number 137 of 2014 concerning National Standards for Early Childhood Education, 2014).

Teachers must have skills in dealing with difficult situations, including when a disaster occurs (Fitriyah, 2017). Data from observations and interviews with school teachers in Surabaya and Sidoarjo Kindergartens found early childhood, namely the lack of understanding of children about earthquake disaster preparedness. The observations show that the implemented disaster preparedness learning activities are pretty varied, such as through storytelling, demonstrations, and field trips by applying the classical learning model. Utilizing existing items as learning media such as storybooks, buoys, and improvisation of objects around the school is enough for children to experience disaster depictions even though they have not provided real simulations. Socialization activities for disposing of garbage in its place, showing various pictures of disasters, and telling stories about disasters that are deemed unable to attract children's interest in learning, so we need a medium to develop disaster preparedness, especially earthquakes that are following children's interests to solve problems in learning activities about disasters.

Learning media by utilizing knowledge, innovation, and education to build a culture of safety and resilience is very important in reducing disaster risk (Astuti \& Sudaryono, 2010). Arifianti (2016) supported this, which states that good disaster management should be integrated with the education sector and can be started early (children from kindergarten to high school levels). The results of previous research prove that one of the effective ways to provide learning about the learning environment with critical thinking is to use media that is scientific or attractive to children (Agustin, 2019; Kusumaning Ayu et al., 2019; Jannah et al., 2021).

The ASIAB shirt or the let's disaster prepared shirt is an early childhood learning medium that introduces earthquake disaster preparedness. This media includes non-projection visual media in the form of a model that is the first and unprecedented child safety media packaged practically. ASIAB clothing media is designed to introduce the importance of children's safety when a disaster occurs. The combination of two clothing and bag media components is expected to attract children's interest in learning through appearance, size, and color according to the child's preferred age. Efforts to raise awareness of disaster alerts from an early age are implementing ASIAB clothing media in learning.

The ASIAB shirt is a multifunctional learning medium wherein delivering earthquake disaster material, children are invited to know pre-disaster, during a disaster, and post-disaster actions, so that the formation of earthquake response character can be achieved. Children can know what an earthquake is and know how to save themselves without feeling confused and panicking in the face of a disaster through real experiences, as an effort to save themselves during a disaster by directly demonstrating a disaster preparedness attitude. Learning media for early childhood earthquake disaster preparedness is a medium with long-term benefits, which aims to shape the character of a resilient and responsive nation. Children can also share disaster knowledge as parties who play a role in the change in the family and participate in efforts to prevent and reduce the risk of earthquake disasters (Koswara et al., 2019).

Previous research has stated that knowledge of disasters regarding floods from an early age, disaster preparedness training from school age can increase understanding of flood disaster preparedness and resilience to flood disasters (Boon \& Pagliano, 2015; Bosschaart et al., 2013; 
Farid et al., 2012; Kortenkamp \& Basten, 2015; Rochman et al., 2018; Fitriyah, 2019; Kurniasih et al., 2020). The results of interviews and several relevant studies related to child disaster preparedness education show that, there is still no discovery of disaster prepared clothing media for early childhood, so it is important to develop ASIAB clothing media to support the learning process for disaster preparedness. Based on these problems, the formulation of the problem in this study is the development, effectiveness, and suitability of ASIAB clothing media for early childhood disaster preparedness.

\section{B. Methodology}

This study uses the ADDIE model. The choice of this model is because it is easy to apply and has simple steps in developing a product to solve learning problems in accordance with the development of ASIAB clothing media products which aims to assist the learning process for earthquake disaster preparedness to develop aspects of children's physical motor development in the scope of health and safety behavior (Rusdi, 2018). The advantages of choosing this development model are (1) it is appropriate to use as a basis for developing a learning system, (2) describes a systematic and complete explanation, (3) conducts an assessment stage by experts, so that before testing the product, it has been revised first by the expert. Tegeh et al., (2014) stated that the stages of development research in the ADDIE model consist of five stages, namely: (1) analysis, (2) design, (3) development, (4) implementation and (5) evaluation.

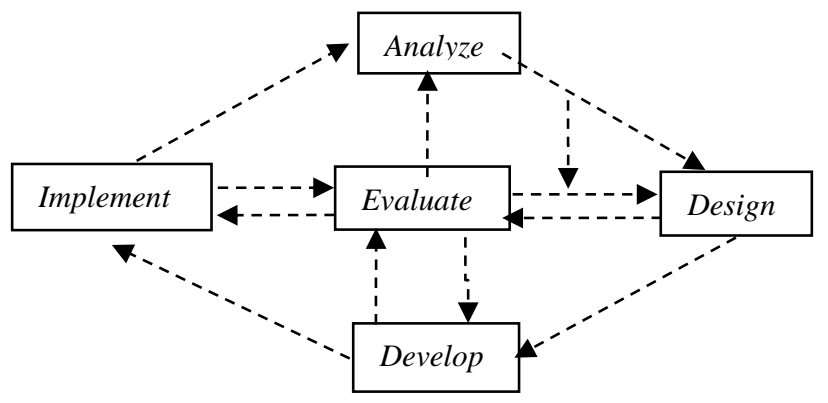

Figure 1. Concept of ADDIE Model (Tegeh et al., 2014)

In this ASIAB clothing media development research, the trial subjects were 30 teachers, media experts, and material experts. The product is validated first before being tested on a research sample (teacher). Validation of product feasibility is obtained by considering the input of experts as a material for making improvements, continued with conducting trials on research samples (teachers) which aims to determine the feasibility and effectiveness of products in early childhood disaster preparedness learning.

Observations in several schools first carried out the data collection method to determine the problem of learning earthquake disaster preparedness and to find out the extent of children's knowledge about earthquake disasters. These preliminary observations are needed to support the formulation of problems in the ASIAB clothing media development research and as a background for conducting research. The second stage was conducting structured interviews with class teachers to find out the school's needs regarding introducing earthquake disaster preparedness material quickly and pleasantly to children according to the learning objectives.

This development research uses an online trial design using a questionnaire with the help of the google form system. The questionnaire was distributed to the research sample (teachers) 
according to predetermined qualifications. The teacher provides an assessment of ASIAB clothing media development products by filling in the Google form that has been provided. The assessment is carried out first by looking at the video on ASIAB clothing on the Google Form (video link is also available). The teacher provides supportive input for product improvement for further research. After completing the assessment, the teacher was also asked to share a video on the use of ASIAB clothing media to student guardians to disseminate innovation in earthquake preparedness learning media.

The process of developing ASIAB clothing media which has gone through the revision stage accompanied by input from experts, is qualitative data. The assessment results of the feasibility and effectiveness of the ASIAB clothing media on early childhood disaster preparedness are quantitative data. Data analysis using interview and questionnaire techniques. The data measurement process was carried out using a Likert scale with very good, good, good enough, not good, and very bad gradations in descriptive analysis. The value of the results obtained is calculated using a quantitative formula with a score of 5, 4, 3, 2, 1, where the biggest score is a very good gradation (Sugiyono, 2015). The table of criteria for assessing the feasibility and effectiveness, according to Riduwan (2008), is as follows:

Table 1. Product Feasibility and Effectiveness Level Assessment Criteria

\begin{tabular}{|c|c|c|}
\hline Kriteria & Presentase & Keterangan \\
\hline Very good & $81 \%-100 \%$ & Very worthy \\
\hline Good & $61 \%-80 \%$ & Worthy \\
\hline Pretty good & $41 \%-60 \%$ & Pretty decent \\
\hline Not good & $21 \%-40 \%$ & Not feasible \\
\hline Not very good & $0 \%-20 \%$ & Very unworthy \\
\hline
\end{tabular}

\section{Result}

This research was conducted in kindergartens around the Surabaya and Sidoarjo areas with 30 teachers as research subjects. The development model is ADDIE which consists of five stages used in the development of ASIAB clothing media products, namely as follows:

1. Analysis

This stage is to obtain data by analyzing several aspects, namely performance analysis, analysis of student characteristics, identification of required sources, and preparation of activity plans.

a. Performance analysis

Analysis of the problem shows that a number of children have not been able to understand the material about earthquake disasters, this can be seen when the teacher asks questions about their knowledge of earthquake disasters, but not all children respond to these questions, so it can be concluded that children need media innovation that is fun and appropriate. use as a solution to the problem at hand.

b. Analysis of the characteristics of students

Data were obtained in the form of characteristics of children in general, namely children who get bored easily and have difficulty concentrating, have high curiosity about something, and prefer to spend their time playing. Students with different backgrounds, such as coming from different areas, children with special needs, children of different 
beliefs and so on require schools to have their own way of educating their students. ASIAB clothing learning media is a fun medium that can deal with these differences.

c. Identify the sources needed

In this stage, an indicator of the level of attainment of the capacity is obtained by referring to the disaster preparedness parameters for early childhood. Things that need to be measured are the aspects of knowledge and attitudes towards earthquake disasters, earthquake emergency plans, and earthquake disaster warnings.

d. Preparation of activity plans

The research activity began by determining and collecting data related to ASIAB clothing media, and continued by compiling a questionnaire for experts and teachers in the form of a google form. Making a video of the procedure for using ASIAB clothing media was also carried out to facilitate the assessment. The evaluation stage can determine whether the ASIAB clothing media is effective and suitable for use in early childhood disaster preparedness learning.

\section{Design} follows:

Products will be made through the design stage or design. The design stages are as

a. Arrangement of instruments

The earthquake disaster preparedness instrument is prepared based on the parameters of disaster preparedness according to LIPI (Triyono et al., 2014), which is adjusted to the characteristics of early childhood aimed at teachers.

b. Selection of trial design

The product development trial design was carried out by using a questionnaire that was distributed via a google form link along with a supporting video link, namely a video on the procedure for using ASIAB clothing media that had been made by the researcher.

c. Product design

The details of ASIAB clothing media product design are as follows:

Table 2. ASIAB Clothing Product Design Details

\begin{tabular}{|r|l|l|}
\hline No. & Development Aspects & \multicolumn{1}{c|}{ Information } \\
\hline 1. & Material selection & $\begin{array}{l}\text { a. ASIAB's shirt and bag material is American Drill Bulltop fabric } \\
\text { b. ASIAB clothes and bags use complementary materials, namely, kretekan, bag } \\
\text { clips, rubber, whistles, reflector tape and zippers. }\end{array}$ \\
\hline 2. & $\begin{array}{l}\text { Size and color } \\
\text { product }\end{array}$ & $\begin{array}{l}\text { a. ASIAB dress size is } 52 \mathrm{~cm} \text { (length), } 41 \mathrm{~cm} \text { (width), } 21 \mathrm{~cm} \text { (neck } \\
\text { circumference), } 30 \mathrm{~cm}(\text { sleeve length). } \\
\text { b. ASIAB bag sizes are } 36 \mathrm{~cm} \text { (length) and } 30 \mathrm{~cm} \text { (width) } \\
\text { c. The colors of ASIAB's clothes and bags are red and yellow }\end{array}$ \\
\hline 3. & Product shape & $\begin{array}{l}\text { This product consists of two parts: the ASIAB shirt and the ASIAB bag. The } \\
\text { following is part of each of these products: } \\
\text { Clothes } \\
\text { a. Shape children's clothes } \\
\text { b. Long sleeved shirt } \\
\text { c. Straight collared shirt } \\
\text { d. The shirt has 4 front pockets } \\
\text { e. Shirt pocket with reflector tape } \\
\text { f. There is a whistle on the right arm }\end{array}$ \\
\hline
\end{tabular}




\begin{tabular}{|l|l|l|}
\hline No. & Development Aspects & \multicolumn{1}{c|}{ Information } \\
\hline & & $\begin{array}{l}\text { g. There are straps and bag clips on the shoulders and waist of the shirt } \\
\text { Bag } \\
\text { a. The shape of a children's bag } \\
\text { b. Large pockets with variations of zippers and kretekan. } \\
\text { c. Front half circle crimped pocket } \\
\text { d. The pockets are wrinkled on the right and left. } \\
\text { e. There are straps and bag clips on the shoulders and waist of the bag } \\
\text { a.f. The front of the bag has a reflector tape }\end{array}$ \\
\hline
\end{tabular}

d. Product Plan

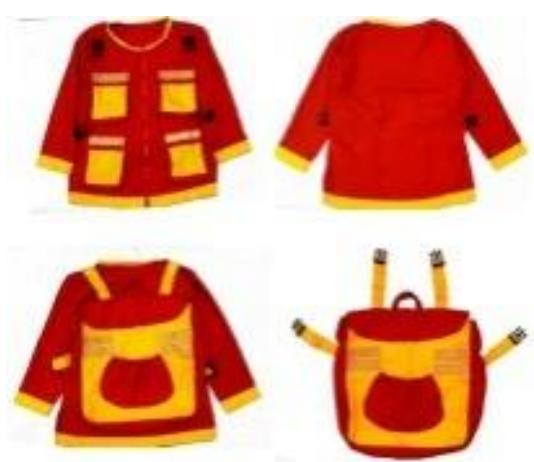

Figure 2. Product Plan

\section{Development}

At this stage the product design is realized into a real ASIAB clothing medium. The product development steps are as follows:

\section{a. Design development}

The design of ASIAB clothing media has unique characteristics, namely by referring to certain standards that have been established in the manufacture of PPE (Anizar, 2012). The manufacture of ASIAB clothing media also refers to the provisions or instructions for personal protective clothing, which are as follows: (1) Capable of reducing harm, (2) As per user size (fit, not tight or loose), (3) Clothes pockets do not contain sharp objects, (4) Made of drilll, cloth coated with aluminum, plastic, leather and asbestos (5) Can protect the body from outside conditions (Jerusalem, 2011).

The following is the Standard Operational Procedure for ASIAB clothing media for pre-disaster preparedness: (1)ASIAB clothing media should be stored in a clean and closed place when not in use. (2) The media is made of fabric, so it needs to be treated to make it durable by washing it at least once a month (it's better to wash it after every use).

(3) If it is necessary to iron, the temperature should not be too hot.

The ASIAB clothing media maintenance procedure is as follows: (1) ASIAB clothes are washed regularly according to the instructions above. (2) ASIAB bags contain items with different characteristics, so they have different treatments, namely as follows: (a) Valuable files such as photocopies of family cards, identity cards, savings books, and certificates can be stored in waterproof plastic or mica and stored in a large ASIAB bag. (b) Supplies such as bottled drinking water, snacks, first aid kits, toiletries, wet tissue, flashlights, spare batteries, cell phones, chargers, power banks and masks need to be checked at least once a month according to their expiration and function. (c) Changing clothes in the form of long sleeves, trousers and underwear also need to be checked for cleanliness at least once a month. 
There are 5 practical steps that can be applied in the use of ASIAB clothing media as follows: (1) Take the ASIAB shirt, (2) The right hand is inserted into the hole of the right sleeve of the ASIAB shirt, (3) The left hand is inserted into the hole of the left sleeve of the shirt, (4) Glue the ASIAB shirt and sound the whistle, (5) Take the ASIAB bag and place it on your head.

The application of the steps for using ASIAB clothing media lasts 6 seconds at each step. Children are invited to be skilled and responsive in responding to earthquake events. The use of ASIAB clothing media after a disaster is as follows: (1) ASIAB clothes are used to protect the body after a disaster, while the ASIAB Bag is used as a place to store personal needs. ASIAB clothes can be used after a disaster to protect the body from outside dangerous conditions or as an anticipation for protection against aftershocks. (2) The ASIAB bag can be used after being in an evacuation site (field or disaster post) according to current needs, namely such as: (a) Important documents can be used when personal documents are needed for identification purposes. (b) Snack and drink can be consumed when you need food or drink because you are hungry and thirsty. (c) First aid kit can be used when medicine is needed. (d) Masks can be used when the air is polluted by the earthquake. (e) Toiletries are used when cleaning yourself. (f) Clothes can be used when you want to change dirty clothes that are being used. (g) Flashlight can be used when lighting is needed in the dark. (h) Communication tools can be used to contact medical personnel and find out information regarding the condition of the disaster-affected area and the risk of a further disaster. (i) The battery can be used when the flashlight battery runs out, as well as a cellphone charger to charge an exhausted cellphone.

The use of needs is tailored to the personal needs of the time. Children can be introduced to the overall disaster preparedness attitude up to the evacuation stage or at certain stages only by using ASIAB clothing as an earthquake disaster preparedness simulation activity.

\section{b. Theme development}

ASIAB clothing media can be applied to learning the theme of the universe. The same benefits can be obtained, namely the application of learning other disaster sub-themes in the pre and post disaster phases. The aspects of early childhood development can be stimulated as a whole by using ASIAB clothing media.

c. Video making

This stage was made of making a video which aims to make it easier for the research subject to provide an assessment of the development of ASIAB clothing media. The video is uploaded after going through the editing process and the approval of the supervisor. Here is the video link that was created (https://youtu.be/Sp-OA-mI6D8).

\section{d. Preparation of a questionnaire or questionnaire}

The activity of compiling a questionnaire or questionnaire is carried out by researchers in consultation with advisors and experts. Questionnaires that can be declared appropriate and in accordance with the research topic, are changed in the form of google form and distributed to research subjects accompanied by video links on the procedures for using ASIAB clothing media. 


\section{Implementation}

The trial implementation stage aims to determine the effectiveness and feasibility of the product. The implementation is as follows:

a. Products that have gone through the development stage are continued with the expert validation stage. Validation is carried out to obtain product eligibility by media and material experts. The percentage value of the validation results from media experts is $73.33 \%$, including good criteria with appropriate information. The percentage value of material expert validation results is $90.67 \%$ including very good criteria with appropriate information. The percentage acquisition of expert validation is shown in Table 2 and Figure 2 below.

Table 3. Percentage of Expert Validation

\begin{tabular}{|c|c|c|}
\hline Validator & Percentage & Information \\
\hline $\begin{array}{c}\text { Material } \\
\text { expert }\end{array}$ & $90.67 \%$ & Very good \\
\hline Madia expert & $73.33 \%$ & Good \\
\hline
\end{tabular}

b. The next stage was assessed by 30 teachers in kindergartens in the Surabaya and Sidoarjo regions to determine the feasibility and effectiveness of the product. The assessment was carried out using a google form accompanied by a video on the use of ASIAB clothing media. The questionnaire was prepared based on product feasibility indicators and product effectiveness indicators, namely referring to the disaster preparedness parameters of LIPI according to the characteristics of early childhood. The percentage of teacher assessments can be seen in table 2 and Figure 5 below.

Table 4. Teacher Rating Percentage

\begin{tabular}{|l|c|c|l|c|c|}
\hline No. & Percentage & Total & No. & Percentage & Total \\
\hline 1. & $70 \%$ & 1 & 9. & $82 \%$ & 2 \\
\hline 2. & $72 \%$ & 1 & 10. & $83 \%$ & 1 \\
\hline 3. & $73 \%$ & 1 & 11. & $84 \%$ & 2 \\
\hline 4. & $74 \%$ & 1 & 12. & $87 \%$ & 2 \\
\hline 5. & $76 \%$ & 1 & 13. & $88 \%$ & 1 \\
\hline 6. & $78 \%$ & 2 & 14. & $95 \%$ & 2 \\
\hline 7. & $80 \%$ & 5 & 15. & $99 \%$ & 1 \\
\hline 8. & $81 \%$ & 3 & 16. & $100 \%$ & 4 \\
\hline \multicolumn{5}{|l}{ Total sampel } \\
\hline \multicolumn{4}{|l}{ Sub total sampel } & 15 & \multicolumn{5}{l}{ Total sampel } & 30 \\
\hline
\end{tabular}

Based on calculations using the quantitative data formula by adjusting the percentage of eligibility criteria and product effectiveness, the teacher questionnaire percentage value is $84.33 \%$ with very good criteria and includes appropriate information.

\section{Evaluation}

The evaluation phase begins with providing guidance to experts regarding the development of ASIAB clothing media products and obtaining input for revising until the product is declared fit for use as a research instrument. The percentage value of validation results from media experts is $73.33 \%$ with good criteria including the appropriate information. The percentage value of the validation result of material experts is $90.67 \%$ with very good criteria including the appropriate 
information. The percentage results in accordance with the assessment criteria indicate that the product is suitable for use to be continued at the research stage. The evaluation by the teacher is carried out after passing the evaluation of the experts. The percentage results obtained were then calculated as an overall average with a value of $84.33 \%$, so it can be concluded that the ASIAB clothing media is feasible and effective to be used in earthquake disaster preparedness learning.

\section{Discussion}

Earthquake disasters occur so fast that escape procedures by dropping (ducking), covering (protecting the head), and holding on (holding on) need to be mastered beforehand as a disaster preparedness effort (National Disaster Management Agency, 2018). Disaster preparedness is one of the four cycles of disaster management to prevent casualties and losses in all aspects of life (Wesnawa \& Christiawan, 2014). Knowledge of earthquake disaster preparedness steps needs to be possessed by each individual, such as knowing pre-disaster, during a disaster, and post-disaster measures. The character building of earthquake disaster response can be achieved (National Disaster Management Agency, 2017).

Disaster preparedness is a plan to protect against harmful threats from the outside due to natural and non-natural factors (Law of the Republic of Indonesia Number 24 of 2007 concerning Disaster Management, 2007). Earthquake disaster preparedness needs to be introduced from an early age because children are classified as vulnerable groups who must receive protection when a disaster occurs (Amir et al., 2017). Children are invited to actively participate in developing themselves to gain knowledge of preparedness to reduce the risk of disasters occurring (Purwani et al., 2019).

Providing pre-disaster knowledge to children through disaster risk reduction activities is the right time to develop potential disaster preparedness (Heri \& Caesar, 2018). Purwani (2019) adds that children can participate when a disaster occurs, so there is a need for early education about disasters. Child protection efforts through the provision of various daily activities can foster a sensitive attitude and children's social interactions in responding to events that occur in the surrounding environment. The stimulation of appropriate preparedness has a positive impact on children to understand the importance of self-awareness and mental toughness to always be vigilant in facing disasters.

Children naturally can recognize various hazard alarms (such as fire, flood, and earthquake) and recognize situations that can endanger them. These indicators are listed in Permendik No. 137 of 2014 regarding the national standard of early childhood education. In line with making ASIAB clothing media stimulate children's preparedness against disasters, this is one aspect of developing children's ability to save themselves. The results of the study state that there are still problems in the selection of teaching media that impact children's knowledge, attitudes, and effective behavior (Tuswadi \& Hayashi, 2014). ASIAB clothing media is a solution to help children more easily understand disaster preparedness material by doing hands-on practice through earthquake disaster simulations.

Earthquake disaster preparedness education appropriate for children can increase understanding of natural phenomena, especially in earthquakes, through the emergency response and disaster mitigation attitudes shown (Pribadi \& Yuliawati, 2008). Early childhood disaster preparedness simulation activities according to LIPI parameters by adjusting the characteristics of early childhood are used as guidelines in the development of ASIAB clothing media. These parameters are also linked to the media's feasibility standards to achieve the criteria for being feasible and effective for disaster preparedness learning. 
The data on the percentage value of acquisition from the teacher questionnaire are shown in table 4, then the overall mean is sought from the 30 research samples that have been determined. Obtained a percentage value of $84.33 \%$, where this percentage is included in the very good criteria for proper information, so it can be concluded that the ASIAB clothing media is feasible and effectively applied in learning activities.

Descriptive data in the form of input and suggestions from several teachers including ASIAB clothing media in stimulating disaster preparedness in children is very good and suitable in stimulating child development. Still, if possible ASIAB clothes are equipped with head protection / hats such as jackets that can be put on / removed, clothing media ASIAB and ASIAB bags have good design alignment. Still, you can add cartoon emblems to make them more attractive to children. Teachers also received innovations regarding practical and fun ways to introduce earthquake disaster preparedness to early childhood with the ASIAB clothing media. This was evident from the suggestions given, such as ASIAB clothing media that needed to be implemented directly in early childhood in earthquake disaster preparedness simulation activities in each school. For teachers, this ASIAB clothing media can help the learning process for children's disaster preparedness.

Learning media is an effective strategic component in supporting the teaching and learning process. According to Edgar Dale, the model is included in the classification of learning media according to the second most concrete level after the direct experience. A model is an artificial three-dimensional object which is a substitute for the real object. Models are used in learning to overcome the availability and limitations of reality objects (Wiarto, 2016). Model or artificial objects can be used to provide real experiences directly to children.

ASIAB clothing media includes non-projection visual media in the form of a model, which is the first child safety medium and has never existed before. In line with Wati's research (2016), which states that the use of non-projection visual media in learning can help explain something that is initially abstract to become more authentic, making it easier to understand the material provided in accordance with Edgar's theory of experience. Other positive impacts obtained in the learning process, such as the passive attitude of children, communication in learning, and the limitations of classrooms and learning media, can be overcome (Wati, 2016). This supports the development of ASIAB clothing media where children are invited to learn directly through real experiences of earthquake disaster preparedness materials.

The feasibility of ASIAB clothing media refers to the media criteria according to Arsyad (2013), including the quality of content and product objectives such as important, precisely balanced, complete, and in accordance with the needs and characteristics of early childhood. The quality of instruction is also a consideration in designing ASIAB clothing media such as being flexible, motivating, as a tool, holistic learning, teaching innovation, inviting active learning and communication.

ASIAB clothing media was created by prioritizing the user's personal safety in pre and post-earthquake disasters on the basis of the idea of a combination of safety clothes and disaster preparedness bags. Safety clothes are body protective equipment that functions to protect yourself from external influences such as sparks, hot sun, cold rain, oil, chemical liquid spills. The safety clothing material used is usually designed using drill cloth, aluminum-coated cloth, or leather. Safety clothes prioritize the comfort and safety of the wearer, which are designed not to be too tight, not stiff, and also not too loose, so they don't limit them when moving (Jerusalem, 2011).

The ASIAB shirt is a special child safety outfit that functions to stimulate disaster preparedness capabilities at an early age. The manufacture of ASIAB clothes is based on making 
personal protective equipment, namely comfortable to wear, easy to move when worn, serves to protect oneself, easy to maintain, and the right size (Anizar, 2012). ASIAB dress size is adjusted to the body size of early childhood in general (all size). The provisions of safety clothing guide the selection of ASIAB clothing materials, and the design of the clothes making refers to the characteristics of early childhood. This is evident from the data on respondents who state that the ASIAB clothing media is in accordance with the aspects of the child and is suitable for use by early childhood.

A disaster preparedness bag is an important need and a top priority that needs to be prepared in the face of a disaster, namely to store basic needs in order to survive (Mulyadi, 2017). Disaster preparedness education can be started from simple things in the form of a backpack filled with needs according to family members with extraordinary benefits (National Disaster Management Agency, 2017). This ASIAB bag has the same definition and function as an emergency preparedness kit, which is used to store one's personal needs to survive in an emergency while waiting for help to arrive. The kinds of needs needed in disaster preparedness can be socialized and introduced to children by applying ASIAB clothing media in disaster material. The application of these media helps children name and plan the needs needed to save themselves.

The development of ASIAB clothing media is related to the importance of introducing disaster preparedness from an early age. Children's awareness can increase significantly after going through a series of disaster preparedness activities to form anti-assurance, identification, and self-control abilities (Brunner \& Lewis, 2006). ASIAB clothing media teaches children to recognize disasters, be prepared before, during, and before an earthquake, plan for personal needs, recognize dangerous alarms and stimulate overall aspects of child development, and teach children about the importance of trying to get out of difficult situations (Fitriyah et al. al., 2020).

\section{E. Conclusion}

The development of ASIAB clothing media products which aim to stimulate the physical aspects of children's motoric development in the scope of health and safety behavior is excellent and suitable for use as a research instrument in helping the learning process of early childhood earthquake disaster preparedness. The results of the assessment of the research subjects show that the use of each component of the ASIAB clothing media can introduce disaster preparedness to children, such as sounding a whistle can introduce alarm sounds in simulation activities. ASIAB bags help children plan basic needs for disaster preparedness independently. ASIAB clothes introduce concepts of Personal safety from an early age. Media design can motivate children to be more enthusiastic about learning earthquake disaster preparedness and make it easier for children to introduce the stages of earthquake disaster preparedness.

\section{F. Recommendation}

In the next research, it is hoped that all research subjects can experience directly related to disaster simulations and can be developed regarding the addition of headgear or hats, removable jackets and cartoon emblems, so as to increase children's interest in ASIAB clothes.

\section{G. References}

Agustin, N. (2019). Pengaruh Pendekatan Saintifik Terhadap Keterampilan Berpikir Kritis Siswa Subtema Keberagaman Makhluk Hidup Di Lingkunganku Kelas IV Sekolah Dasar. Child Education Journal, 1(1), 36-43. https://doi.org/10.33086/cej.v1i1.912 
Amir, M. Y., Sulfiati, \& Basry, W. (2017). SIMULASI KESIAPSIAGAAN BENCANA GEMPA BUMI DALAM UPAYA MENGURANGI RESIKO BENCANA DI SD MUHAMMADIYAH 2 PALU. SiIMO Engenering Fakultas Teknik Universitas Muhammadiyah, 1, 1-7.

Anizar. (2012). Teknik Keselamatan dan Kesehatan Kerja di Industri. Graha Ilmu.

Arifianti, Y. (2016). Buku Mengenal Tanah Longsor Sebagai Media Pembelajaran. Bulletin Vulkanologi Dan Bencana Geologi, January. https://www.researchgate.net/profile/YukniArifianti/publication/290437737_BUKU_MENGENAL_TANAH_LONGSOR_SE BAGAI_MEDIA_PEMBELAJARAN_BENCANA_SEJAK_DINI/links/56985d6b 08aec79ee32b835a/BUKU-MENGENAL-TANAH-LONGSOR-SEBAGAIMEDIA-PEMBELAJARAN-BENCANA-SEJAK-DINI.p

Arsyad, Azhar. (2013). Media Pembelajaran. PT Raja Grafindo Persada.

Astuti, S. I., \& Sudaryono, S. . (2010). Peran Sekolah dalam Pembelajaran Mitigasi Bencana. Jurnal Dialog Penanggulangan Bencana, 1(1), 30-42.

Badan Nasional Penanggulangan Bencana. (2017). Buku Saku Tanggap Tangkas Tangguh Menghadapi Bencana. Badan Nasional Penanggulangan Bencana, 62. https://siaga.bnpb.go.id/hkb/po-content/uploads/documents/Buku_Saku10Jan18_FA.pdf

Badan Nasional Penanggulangan Bencana. (2018). Panduan Kesiapsiagaan Bencana Untuk Keluarga. 1-64.

Boon, H. J., \& Pagliano, P. J. (2015). Disaster Education in Australian Schools. Australian Journal of Environmental Education, 30(2), 187-197.

Bosschaart, A., Kuiper, W., Schee, J. van der, \& Schoonenboom, J. (2013). The role of knowledge in students' flood-risk perception. Natural Hazards, 69(3), 1661-1680.

Brunner, J., \& Lewis, D. (2006). Principal leadership. 6(8), 65-66.

Undang-Undang Republik Indonesia Nomor 24 Tahun 2007 tentang Penanggulangan Bencana, Kementrian Hukum dan Hak Asasi Manusia Republik Indonesia (2007).

Farid, M., Mano, A., \& Udo, K. (2012). Urban flood inundation model for high density building area. Journal of Disaster Research, 7(5), 554-559. https://doi.org/10.20965/jdr.2012.p0554

Fitriyah, F. K. (2017). Reducing Aggressive Behavior Using Solution-Focused Brief Counseling (SFBC). JBKI (Jurnal Bimbingan Konseling Indonesia), 2(2), 34-39. https://doi.org/http://dx.doi.org/10.26737/jbki.v2i2.254

Fitriyah, F. K. (2019). Pengaruh Perilaku Agresif pada Anak Usia Dini terhadap Kecemasan dan Empati. Education and Human Development Journal, 3(1), 96102. https://doi.org/https://doi.org/10.33086/ehdj.v4i1.1088

Fitriyah, F. K., Saputra, N., Dellarosa, M., \& Afridah, W. (2020). Does spirituality correlate with students' empathy during covid-19 pandemic? the case study of Indonesian students. Couns-Edu: The International Journal of Counseling and Education, 5(3). https://doi.org/https://doi.org/10.23916/0020200527820

Heri, H., \& Caesar, R. (2018). Kesiapsiagaan Menghadapi Bencana Berbasis Sekolah. Jurnal Academia Praja, 1(02), 91-106. https://doi.org/10.36859/jap.v1i02.67

Jerusalem, M. A. (2011). Keselamatan Kesehatan Kerja dan Lingkungan Hidup. PT. Intan Sejati Klaten.

Jannah, Z., Fauziah, N., Ningsih, T. N., Kusumaning, R. F., Suryadi, D. A., Putri, R., Budiarti, N., \& Fitriyah, F. K. (2021). Planetarium Glass Based on Augmented Reality to Improve Science Literacy Knowledge in Madura Primary Schools. 3(1), 19-29. 
Kortenkamp, K. V., \& Basten, B. (2015). Environmental Science in the Media: Effects of Opposing Viewpoints on Risk and Uncertainty Perceptions. Science Communication, 37(3), 287-313.

Koswara, A., Amri, A., Zainuddin, F. K., Ngurah, I., Muzaki, J., Muttmainnah, L., Utaminingsih, M., Saleky, S. R. J., Widowati, \& Tebe, Y. (2019). “Mewujudkan Satuan Pendidikan Aman Bencana di Indonesia.” Kementrian Pendidikan dan Kebudayaan.

Kurniasih, V. W., Fitriyah, F. K., Hidayat, M. T., \& Sunanto. (2020). Hubungan Pemahaman Diri Terhadap Rasa Tangung Jawab: Sebuah Survey pada Anak Usia Dini di Kota Surabaya. Child Education Journal, 2(2), 98-105. https://doi.org/10.33086/cej.v2i2.1672

Kusumaning Ayu, R. F., Puspita Sari, S., Yunarti Setiawan, B., \& Khoirul Fitriyah, F. (2019). Meningkatkan Kemampuan Berbahasa Daerah Melalui Cerita Rakyat Digital pada Siswa Sekolah Dasar: Sebuah Studi Pengembangan. Child Education Journal, 1(2), 65-72. https://doi.org/10.33086/cej.v1i2.1356

Marolli. (2017). BNPB Menginisiasi Pencanangan Hari Kesiapsiagaan Bencana. Kementrian Komunikasi Dan Informatika Republik Indonesia. https://kominfo.go.id/content/detail/9571/bnpb-menginisiasi-pencanangan-harikesiapsiagaan-bencana/0/artikel_gpr

Mulyadi, T. (2017). Buku Petunjuk Singkat Penggunaan Tas Siaga Bencana (Emergency Preparedness Kit). BNPB. https://bpbd.jakarta.go.id/assets/attachment/document/Tas_Siaga.pdf.

Peraturan Menteri Pendiidkan dan Kebudayaan Republik Indonesia Nomor 137 Tahun 2014 Tentang Standar Nasional Pendidikan Anak Usia Dini, (2014).

Pribadi, K. S., \& Yuliawati, A. K. (2008). Pendidikan Siaga Bencana Gempa Bumi Sebagai Upaya Meningkatkan Keselamatan Siswa (Studi Kasus Pada SDN Cirateun dan SDN Padasuka 2 Kabupaten Bandung).

Purwani, A., Fridani, L., \& Fahrurrozi, F. (2019). Pengembangan Media Grafis untuk Meningkatkan Siaga Bencana Banjir. Jurnal Obsesi : Jurnal Pendidikan Anak Usia Dini, 3(1), 55. https://doi.org/10.31004/obsesi.v3i1.142

Riduwan. (2008). Skala Pengukuran Vaiabel-variabel Penelitian. Alfabeta.

Rochman, C., Yulianti, R. N., Nasrudin, D., \& Malik, A. (2018). Physics concept on flood mitigation in West Java. IOP Conference Series: Materials Science and Engineering, 434(1). https://doi.org/10.1088/1757-899X/434/1/012015

Rusdi. (2018). Penelitian Desain Dan Pengembangan Kependidikan. PT. Raja Grafindo.

Sugiyono. (2015). Statistik Nonparametrik Untuk Penelitian. Alfabeta.

Tegeh, I. M., Jampel, I. N., \& Pudjawan, K. (2014). Model penelitian pengembangan. Graha Ilmu.

Triyono, Kurniah, Nina, A., Titik, K., \& Novi, H. (2014). Pedoman Kesiapsiagaan Menghadapi Gempa Bumi dan Tsunami Berbasis Masyarakat. Badan Nasional Penanggulangan Bencana, December.

Tuswadi, \& Hayashi, T. (2014). Disaster Prevention Education in Merapi Volcano Area Primary Schools: Focusing on Students' Perception and Teachers' Performance. Procedia Environmental Sciences, 20, 668-677. https://doi.org/10.1016/j.proenv.2014.03.080

Wati, E. R. (2016). Ragam Media Pembelajaran Visual - Audio Visual - KomputerPower Point-Internet-Interactive Video. Kata Pena.

Wesnawa, I. G. A., \& Christiawan, P. (2014). Geografi Bencana. Graha Ilmu. 
Putri Diana Sofiya Hidayah and Kartika Rinakit Adhe

ASIAB Clothing Media for Early Childhood Disaster Preparedness

Wiarto, G. (2016). Media Pembelajaran Dalam Pendidikan Jasmani. Laksitas.

Wiyani, N. A. (2016). Konsep Dasar PAUD. Gava Media. 